\title{
Wnt6 influences the viability of mouse embryonic palatal mesenchymal cells via the $\beta$-catenin pathway
}

\author{
ZHENG JIANG $^{1}$, LIN PAN $^{2}$, XIAOLING CHEN ${ }^{1},{\text { ZHIQUN } \text { CHEN }^{1} \text { and DONGWEI XU }}^{1}$ \\ Departments of ${ }^{1}$ Endodontics and ${ }^{2}$ Implantology, Xiamen Stomatological Hospital, Xiamen, Fujian 361000, P.R. China
}

Received February 27, 2017; Accepted July 27, 2017

DOI: $10.3892 /$ etm.2017.5240

\begin{abstract}
The embryological stages of palatal shelf elongation and elevation, mainly induced by the proliferation and extracellular matrix secretion of embryonic palatal mesenchymal (MEPM) cells, are essential for normal palatal development. Wingless-related MMTV integration site gene family (Wnt) signaling pathways serve key roles in craniofacial development and palate formation. Recent studies have indicated that Wnt6 participates in embryonic development of the palate, though its exact role in palate development remains unclear. In the present study, to investigate the role of Wnt6 during the stages of palatal shelves elongation and elevation, mouse MEPM cells were cultured from dissected palatal shelves at embryonic day 13.5. Results of an MTT assay and flow cytometric analysis demonstrated that treatment with recombinant Wnt6 increased the viability of MEPM cells $(\mathrm{P}<0.01)$ and the proportion of cells in the $\mathrm{S}$ and $\mathrm{G} 2 / \mathrm{M}$ phases $(\mathrm{P}<0.01)$. Meanwhile, Wnt6 activated the $\beta$-catenin signaling pathway as indicated by the dual luciferase assay result, and blockade of the WNT/ $\beta$-catenin pathway reduced the cytoactivity of Wnt6 in MEPM cells $(\mathrm{P}<0.01)$. Collectively, these findings indicate that Wnt6 promotes the vitality of MEPM cells by increasing the $\mathrm{S}+\mathrm{G} 2 / \mathrm{M}$-phase cell population, potentially through activation of the $\beta$-catenin pathway during palatal shelf elongation and elevation.
\end{abstract}

\section{Introduction}

Cleft palate is among the most common congenital birth defects in humans (1-3), and is caused by a failure in secondary palate formation $(4,5)$. From embryonic days (E) 12.5 to E15.5, the secondary palate is initiated to extend from the maxillary processes to form the palatal shelves (6). At approximately

Correspondence to: Dr Zheng Jiang, Department of Endodontics, Xiamen Stomatological Hospital, 1309 Lvling Road, Xiamen, Fujian 361000, P.R. China

E-mail: jiangzhengwhu@163.com

Key words: wingless-related MMTV integration site gene family member 6, cleft palate, mouse embryonic palatal mesenchymal cells, cell viability, wingless-related MMTV integration site gene family signaling
E13.5, the bilateral palatal shelves elongate and elevate to form the midline edge seam (7), while the size of the palatal shelves is determined by the proliferation and apoptosis of mouse embryonic palatal mesenchymal (MEPM) cells (8). During this period, disturbances in the normal viability or extracellular matrix secretion of MEPM cells can cause cleft palate (9). These two processes are controlled by complex signaling cascades that are induced by a number of growth factors, including members of the wingless-related MMTV integration site gene family (Wnt) $(8,10,11)$.

The Wnt signaling glycoproteins serve critical roles in cell viability, differentiation, migration, polarity, and death, and thereby regulate embryonic development (12-18). On the basis of their downstream signal transduction, Wnts have been divided into ' $\beta$-catenin-dependent' and ' $\beta$-catenin-independent' signaling proteins. $\beta$-catenin-dependent signaling is defined by the stabilization of $\beta$-catenin, which enters the nucleus and forms a complex with lymphoid-enhancer-binding factor/T cell factor (TCF) DNA-binding proteins to activate transcription of Wnt target genes (12-16). Meanwhile, $\beta$-catenin-independent signaling performed without $\beta$-catenin includes a number of less well characterized intracellular pathways (18-20). In previous studies, the Wnt signaling pathways have been suggested to serve important roles in craniofacial development $(21,22)$ and palate formation $(8,21,23-25)$.

Wnt family member 6 (Wnt6), as a member of the Wnt signaling family, has been reported to be essential for the viability of macrophages (26), myoblasts (27) and stromal cells (28), and to be expressed in mouse embryonic palatal tissue from E12.5 to E14.5 (10). Furthermore, the WNT6-WNT10A cluster has been identified to exhibit linkage and disequilibrium in cleft palate (29). These previous data indicate that Wnt6 participates in embryonic development of the palate. However, the exact role of Wnt6 in palate development remains unclear.

The purpose of the present study was to investigate the effect of Wnt6 in MEPM cells using the MTT assay, flow cytometry, western blot analysis and reporter gene assay. The results suggest that Wnt6 may regulate the viability of palatal mesenchymal cells through the $\beta$-catenin pathway.

\section{Materials and methods}

Ethics statement. This study was carried out in strict accordance with the recommendations in the Guide for the Care and Use of Laboratory Animals of the National Institutes of Health 
(Bethesda, MD, USA) (6). The protocol was approved by the Committee for the Ethics of Animal Experiments of Xiamen University, Xiamen, China (permit no. SCXK2013-0001). All surgical procedures were performed under urethane (Thermo Fisher Scientific, Inc., Waltham, MA, USA) anesthesia $(1.0 \mathrm{~g} / \mathrm{kg}$ via intraperitoneal injection), and all efforts were made to minimize suffering.

MEPM cell culture. A total of 60 female and 20 male wild-type CD1 mice (Charles River Laboratories, Inc., Wilmington, MA, USA) of the same strain were housed at an ambient temperature of $22^{\circ} \mathrm{C}$ with 12 -h light/dark cycle and had access to food and water ad libitum. Mature male and female mice ( 6 weeks old, weighing 17-23 g) were mated overnight, and the presence of a vaginal plug the following morning was designated as E0.5. Primary MEPM cell cultures were established from secondary palatal tissue microdissected from E13.5 mouse embryos (11). The dissected palate shelves were treated with $1 \mathrm{U} / \mathrm{ml}$ dispase II (Roche Diagnostics, Indianapolis, IN, USA) at $37^{\circ} \mathrm{C}$ for $15 \mathrm{~min}(8,30)$. Following removal of the desquamated epithelia, the tissue was digested with $0.25 \%$ trypsin $/ 0.05 \%$ EDTA, and then the dissociated cells were cultured for $48 \mathrm{~h}$ in Dulbecco's modified Eagle's medium/nutrient mixture F-12 (DMEM/F12; Hyclone; GE Healthcare Life Sciences, Logan, UT, USA) with $10 \%$ fetal bovine serum (FBS; Hyclone; GE Healthcare Life Sciences) and $1 \%$ penicillin/streptomycin at $37^{\circ} \mathrm{C}$ in a humidified atmosphere of $5 \% \mathrm{CO}_{2}$ in air. Cells were passaged and seeded at $4 \times 10^{5}$ cells $/ 25 \mathrm{~cm}^{2}$ in DMEM/F12 without FBS and incubated at $37^{\circ} \mathrm{C}$ for $40 \mathrm{~min}$; in such conditions, the epithelial cells adhered more slowly than the MEPM cells. After culturing for $40 \mathrm{~min}$ at $37^{\circ} \mathrm{C}$, the medium without FBS was replaced with fresh DMEM/F12 including FBS and antibiotics to acquire MEPM cells of high purity. Cells at passage 3 cultured at $37^{\circ} \mathrm{C}$ for $8 \mathrm{~h}$ were used for subsequent assays. Experimental cell groups were established, in which cells were always incubated with additional $100 \mathrm{ng} / \mathrm{ml}$ recombinant Wnt6 (Abgent, Inc., San Diego, CA, USA) with or without additional $100 \mathrm{ng} / \mathrm{ml}$ recombinant dickkopf WNT signaling pathway inhibitor 1 (DKK1; R\&D Systems, Inc., Minneapolis, MN, USA) in DMEM/F12 containing $10 \% \mathrm{FBS}$ and $1 \%$ penicillin/streptomycin at $37^{\circ} \mathrm{C}$. In the control cell group, MEPM cells were only cultured with $10 \%$ FBS and 1\% penicillin/streptomycin in DMEM/F12.

MTT assay. The MEPM cells were transferred to 24-well plates (Corning Incorporated, Corning, NY, USA) at a density of $1.6 \times 10^{4}$ cells/well and cultured at $37^{\circ} \mathrm{C}$ in DMEM/F12 with $10 \%$ FBS for $1-4$ days. MTT solution $(5 \mathrm{mg} / \mathrm{ml})$ was added to each well and the plates were incubated at $37^{\circ} \mathrm{C}$ for $4 \mathrm{~h}$. Subsequently, the supernatant was removed and dimethyl sulfoxide $0.5 \mathrm{mg} / \mathrm{ml}$ was added to each well to dissolve the formazan crystals. The optical density at $490 \mathrm{~nm}$ was quantified using the PowerWave XS2 package at daily intervals over the 4-day assay period (BioTek Instruments, Inc., Winooski, VT, USA). Three independent replicates were performed for each cell group.

Flow cytometry. Following treatment with or without Wnt6 or Wnt6 + DKK1 for $48 \mathrm{~h}$ as stated above, the MEPM cells were harvested and fixed in cold $75 \%$ ethanol at $-4^{\circ} \mathrm{C}$ overnight, cells were pelleted and washed twice in $1 \mathrm{x}$ PBS at 1,000 $\mathrm{x} g$ for $5 \mathrm{~min}$ at $4^{\circ} \mathrm{C}$. Subsequently, cells were incubated with $50 \mu \mathrm{g} / \mathrm{ml}$ propidium iodide and $5 \mu \mathrm{g} / \mathrm{ml}$ RNAase at room temperature for $30 \mathrm{~min}$. Following supplementation with $50 \mathrm{mg} / \mathrm{l}$ propidium iodide and incubation in the dark for $1 \mathrm{~h}$ at room temperature, cell cycle analysis was performed using a BD FACS Calibur flow cytometer (BD Biosciences, Franklin Lakes, NJ, USA) and CellQuest Pro 5.1 software (BD Biosciences) with a minimum of 20,000 events for each cell group.

Reporter gene assay. After $48 \mathrm{~h}$ of treatment with or without $100 \mathrm{ng} / \mathrm{ml}$ recombinant Wnt6 as stated above, the MEPM cells were seeded at $1.6 \times 10^{5}$ cells/well onto 12 -well plates, and transient transfections for $5 \mathrm{~min}$ at room temperature were performed using Lipofectamine 2,000 (Invitrogen; Thermo Fisher Scientific, Inc., Waltham, MA, USA). Cells were transfected with $1.6 \mu \mathrm{g}$ of TCF luciferase reporter constructs (Promega Corporation, Madison, WI, USA) (TOPflash or FOPflash, respectively) and $0.08 \mu \mathrm{g}$ of Renilla reniformis gene vectors (Promega Corporation) for normalization. The TOPflash TCF reporter plasmid contains two sets of three copies of the binding site upstream of the thymidine kinase minimal promoter and luciferase open reading frame, while FOPflash contains mutated TCF binding sites and was used as a negative control (31-34). A subset of the cells lacking Wnt6 treatment were also cotransfected with $\beta$-catenin pcDNA $(1.6 \mu \mathrm{g}$; Biocytogen LLC, Beijing, China) as a positive control. Following $48 \mathrm{~h}$ of incubation, the luciferase assay was performed using a Dual Luciferase Assay System kit (Promega Corporation) according to the manufacturer's protocol. Relative luciferase activity was reported as the ratio of firefly/Renilla luciferase activity.

Western blot analysis. Total protein was isolated from cultured MEPM cells after $48 \mathrm{~h}$ of treatment with or without Wnt6 \pm DKK1 using RIPA lysis and extraction buffer (Beyotime Institute of Biotechnology, Haimen, China). Protein quantification was performed with a Bio-Rad DC Protein Assay kit (Bio-Rad Laboratories, Inc., Hercules, CA, USA). The intracellular protein expression levels of $\beta$-catenin and $\beta$-actin and the Wnt6 protein levels in the cell culture supernatant were assessed. To obtain Wnt6 protein from the supernatant, conditioned culture media were collected and concentrated with Amicon ${ }^{\circledR}$ Ultra-4 Centrifugal Filter Units (10,000 NMWL; EMD Millipore, Billerica, MA, USA), then extracted with a Protein Extraction kit II (Applygen Technologies, Inc., Beijing, China), as described previously (22). Equal amounts of protein (60 $\mu \mathrm{g}$ per lane) were separated on $10 \%$ SDS-polyacrylamide gels and transferred onto polyvinylidenedifluoride membranes (Roche Diagnostics). The membrane was blocked in a $6 \%$ non-fat milk solution in Tris-buffered saline with $0.5 \%$ Tween-20 (TBST) (Roche Diagnostics) at room temperature for $1 \mathrm{~h}$, and then incubated with rabbit anti-Wnt6 monoclonal antibody (Abcam, Cambridge, UK; cat. no. ab154144; dilution 1:200), rabbit anti- $\beta$-catenin monoclonal antibody (Abcam; cat. no. ab32572; dilution 1:500) or rabbit anti- $\beta$-actin monoclonal antibody (Wuhan Antgene Biotechnology Co., Ltd, Wuhan, China; cat. no. ANT009; dilution 1:800) overnight at $4^{\circ} \mathrm{C}$. After rinsing with TBST for three times, the goat 
anti-rabbit HRP-conjugated secondary antibody (Wuhan Antgene Biotechnology Co., Ltd., cat. no. ANT020; dilution 1:5,000) was applied to the membranes at room temperature for $1 \mathrm{~h}$. The blot was visualized using SuperSignal West Pico Chemiluminesent Substrate (Thermo Fisher Scientific, Inc.) and the protein bands were analyzed with ImageJ 1.48 software (National Institutes of Health).

Statistical analysis. All quantitative data were presented as the mean \pm standard deviation. Statistical analysis of differences was performed with SPSS 19.0 software (SPSS, Inc., Chicago, IL, USA) $\mathrm{P}<0.05$ was considered to indicate statistical significance. The significance of data was determined by one-way analysis of variance followed by a Bonferroni post-hoc test.

\section{Results}

Wnt6 promotes the viability of MEPM cells. The expression of Wnt6 was identified in primary (control) MEPM cells at E13.5 (Fig. 1). To investigate the effect of Wnt6 on MEPM cell viability, recombinant Wnt6 was added to the culture medium, and cell viability was assessed with an MTT assay. It was observed that the viability of MEPM cells treated with Wnt6 was significantly higher than that of control cells between 2 and 4 days after treatment $(\mathrm{P}<0.01$; Fig. 2$)$.

In addition, the results of flow cytometric analysis indicated that the proportion of primary MEPM cells in $\mathrm{S}+\mathrm{G} 2 / \mathrm{M}$ phases $(29.91 \pm 0.72 \%)$ was significantly increased by treatment with Wnt6 (50.93 $\pm 0.89 \%$; $\mathrm{P}<0.01$; Fig. 3). These findings suggested that Wnt6 promoted the viability of MEPM cells and increased the population of $\mathrm{S}+\mathrm{G} 2 / \mathrm{M}$-phase cells.

Wnt6 activates the $\beta$-catenin/TCF signaling pathway. A TOP flash luciferase reporter assay was performed to investigate whether Wnt6 activates Wnt/ $\beta$-catenin signaling in MEPM cells. Cells treated with Wnt6 or pcDNA- $\beta$-catenin exhibited significantly higher baselines of $\beta$-catenin/TCF-mediated transcriptional activity when compared with the control cells $(\mathrm{P}<0.01)$. In addition, the TOPflash reporter activity did not differ significantly between the Wnt6 and $\beta$-catenin groups (FOPflash data not shown) (Fig. 4). Furthermore, the total amount of $\beta$-catenin was markedly increased in the Wnt6-treated cells when compared with the control cells (Fig. 1).

Blockade of the WNT/ $\beta$-catenin pathway reduces the cytoactivity of Wnt6. DKK1 binds to low density lipoprotein receptor-related protein $5 / 6$ and is considered to be a general canonical Wnt signaling inhibitor (35). In the present study, DKK1 was used to confirm the effect of Wnt6/ $\beta$-catenin signaling on MEPM cell viability. Cells treated with Wnt6 were incubated with or without DKK1. As depicted in Fig. 1, the additional treatment with DKK1 suppressed the expression of $\beta$-catenin. In addition, the results in Fig. 2 demonstrated that DKK1 significantly reduced the Wnt6-mediated increase in cell viability from day 2 post-treatment $(\mathrm{P}<0.01)$. Furthermore, when the Wnt6/ $\beta$-catenin pathway was blocked, the viability of MEPM cells was significantly lower than that of control cells $(\mathrm{P}<0.01)$. A notable decrease in the $\mathrm{S}+\mathrm{G} 2 / \mathrm{M}$ cell proportion was also observed in the DKK1 + Wnt6 group $(20.43 \pm 0.59 \%$;

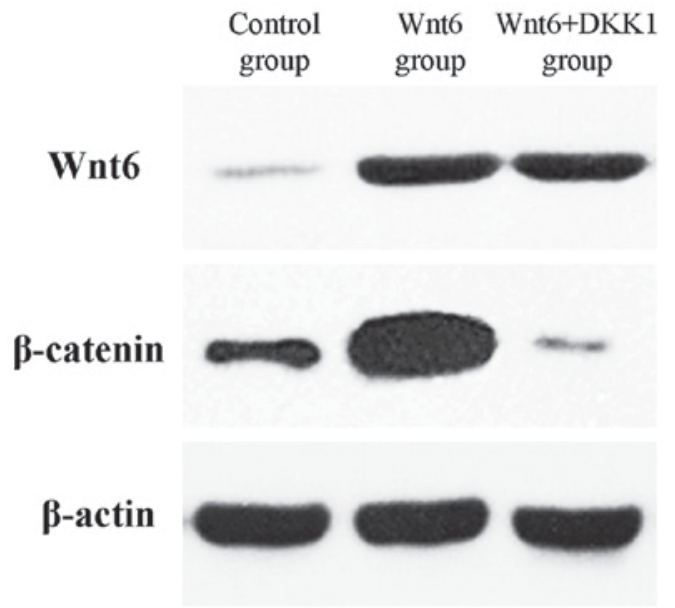

Figure 1. Protein levels of Wnt6 and $\beta$-catenin. Following treatment with Wnt6 or Wnt6 + DKK1 for $48 \mathrm{~h}$, the MEPM cells were harvested and western blotting assays were performed. Intracellular $\beta$-catenin and $\beta$-actin were extracted by cell lysis, and extracellular Wnt6 was extracted from the culture supernatant. Wnt6, wingless-related MMTV integration site gene family member 6; DKK1, dickkopf Wnt signaling pathway inhibitor 1.

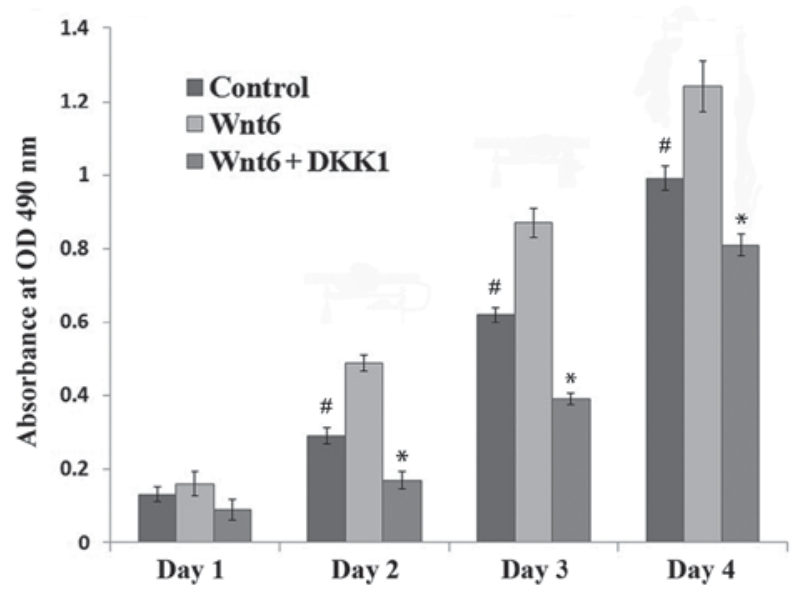

Figure 2. Effect of Wnt6 on the viability of MEPM cells. MEPM cells were treated with or without Wnt6 or Wnt6 + DKK1. The relative absorbance of MEPM cells in an MTT assay was determined at daily intervals over a 4-day assay period. The data were presented as the mean \pm standard deviation $(\mathrm{n}=3) .{ }^{*} \mathrm{P}<0.01$ vs. Wnt6; " $\mathrm{P}<0.01$ vs. Wnt6 + DKK1as indicated. Wnt6, wingless-related MMTV integration site gene family member 6; DKK1, dickkopf Wnt signaling pathway inhibitor 1; mouse embryonic palatal mesenchymal.

Fig. 3) when compared with the control and Wnt6 groups $(\mathrm{P}<0.01)$, and cell cycle arrest in $\mathrm{G} 0 / \mathrm{G} 1$ phase was indicated in the DKK1 + Wnt6 group.

\section{Discussion}

Embryonic development of the palate is a temporospatially coordinated process. The secondary palate is initiated to extend from the maxillary processes to form the palatal shelves between E12.5 and E15.5 (6). At approximately E13.5, the bilateral palatal shelves, composed of a core of mesenchyme cells, elongate and elevate toward each other (7). In the present study, to investigate the role of Wnt6 during the stages of palatal shelf elongation and elevation, MEPM cells were cultured from palatal shelves dissected from mouse 

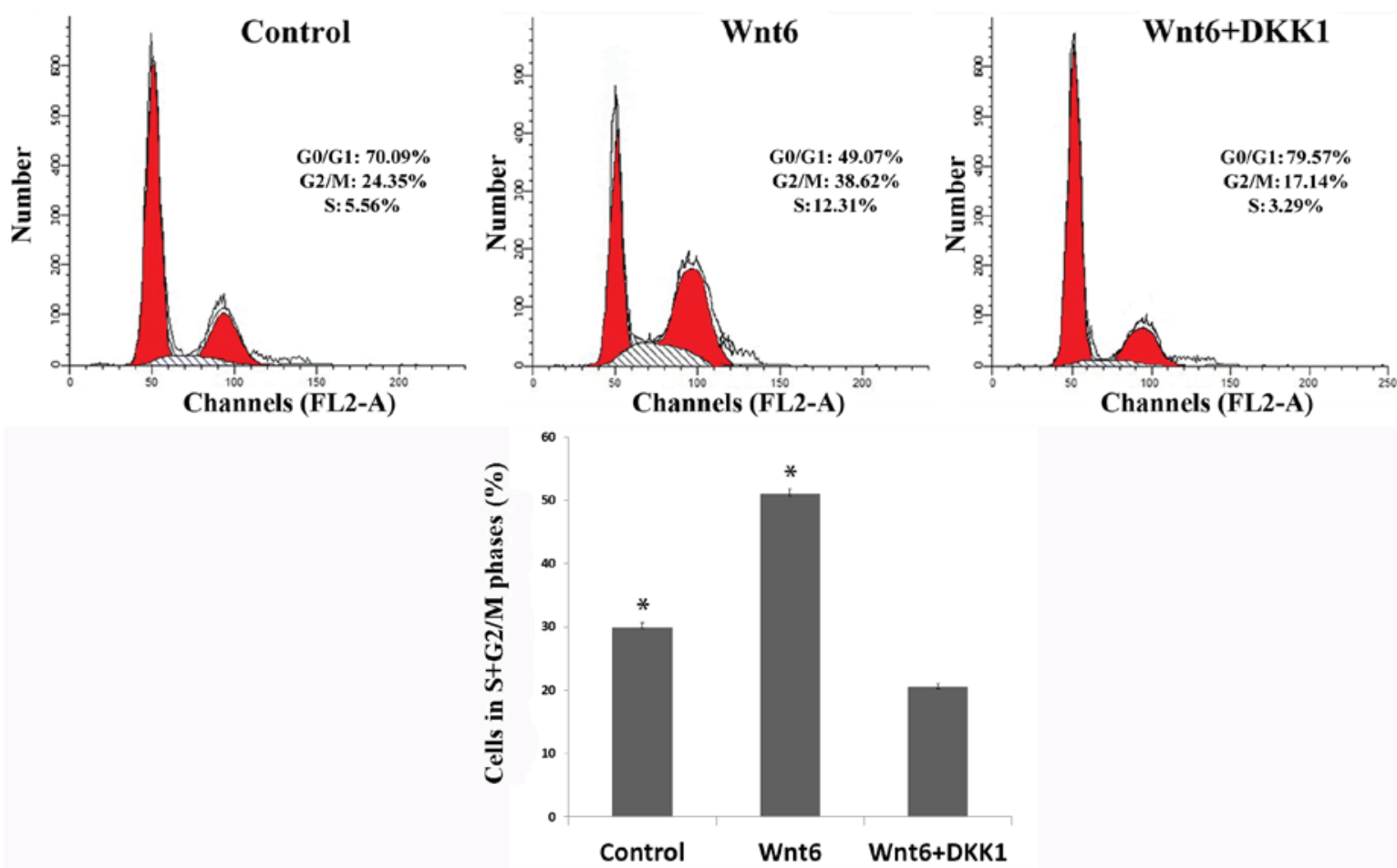

Figure 3. Effect of Wnt6 on the cell cycling of MEPM cells. Flow cytometry analysis of the cell cycle distribution of MEPM cells upon Wnt6 or Wnt6 + DKK1 treatment for $48 \mathrm{~h}$. The data were presented as the mean \pm standard deviation $(\mathrm{n}=3)$. ${ }^{*} \mathrm{P}<0.01 \mathrm{vs}$. Wnt6 + DKK1. Wnt6, wingless-related MMTV integration site gene family member 6; DKK1, dickkopf Wnt signaling pathway inhibitor 1; mouse embryonic palatal mesenchymal.

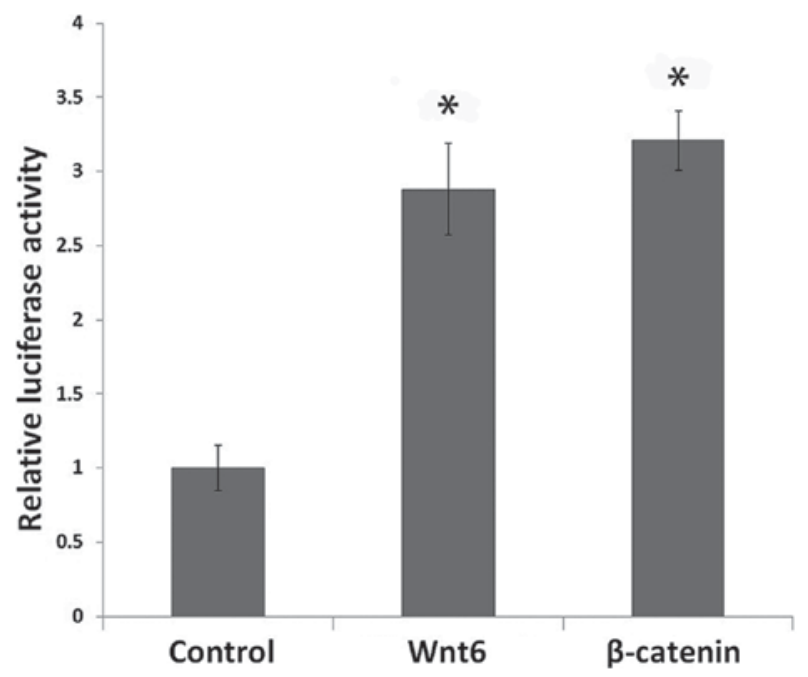

Figure 4. Wnt6 enhances $\beta$-catenin transcriptional activity in MEPM cells. Relative luciferase activity following transfection with TOPFlash or FOPFlash reporter plasmid and cotransfection with pcDNA- $\beta$-catenin or Wnt6 treatment in MEPM cells. The data were presented as the mean \pm standard deviation $(n=3) .{ }^{*} \mathrm{P}<0.01$ vs. control. Wnt6, wingless-related MMTV integration site gene family member 6; mouse embryonic palatal mesenchymal.

fetuses at E13.5. The results of MTT assay and flow cytometry analysis indicated that the viability and $\mathrm{S}+\mathrm{G} 2 / \mathrm{M}$ population of the MEPM cells was increased by Wnt6. Meanwhile, a dual luciferase assay and analysis with DKK1 identified a pivotal role of $\beta$-catenin signaling in the development of MEPM cells. Collectively, the results indicated that Wnt6 promoted the viability of the MEPM cells by increasing the population of
$\mathrm{S}+\mathrm{G} 2 / \mathrm{M}$ cells. The involvement of Wnt6 in the $\beta$-catenin pathway during palatal shelf elongation and elevation was also implicated.

Former studies have already demonstrated that Wnt6 is a necessary cytoactive factor in macrophages (26), myoblasts (27) and stromal cells (28). Wnt6 has also been reported to be expressed in the mouse embryonic palatal tissue from E12.5 to E14.5 (10), and the WNT6-WNT10A cluster exhibits linkage and disequilibrium in cleft palate (29). In the present study, the effect of Wnt6 on MEPM cell viability during embryonic palate development was elucidated in vitro. Further studies into the effects of Wnt6 knockout on palatogenesis in mice should now be performed to identify potentially associated malformations and regulatory mechanisms.

Numerous different factors are involved in the complex transduction of Wnt signals, though particular cells only respond to specific Wnt factors (36). It has been reported that Wnt 6 activates $\beta$-catenin signaling in F9 embryonal carcinoma cells and serves an important role in endoderm specification $(37,38)$ and formation (39). Furthermore, Wnt6 restricted heart muscle development in embryonic mesenchymal cells through the $\beta$-catenin pathway (40), and the osteoblastogenesis of mesenchymal stem cells was regulated by Wnt6/ $\beta$-catenin signaling (41). In the current study, Wnt6 was indicated to stimulate the transcriptional activity of $\beta$-catenin, suggesting that it may activate $\mathrm{Wnt} / \beta$-catenin signaling to enhance the viability of MEPM cells. Treatment with a recombinant version of the Wnt signaling antagonist DKK1 was also performed to verify the relationship between Wnt6 and $\beta$-catenin signaling. The results demonstrated that the increased viability of Wnt6-treated MEPM cells was inhibited by DKK1. This data 
confirmed the stimulatory effect of Wnt6 on the viability of MEPM cells. However, as DKK1 is not a specific inhibitor of Wnt6, further studies are required to confirm the exact signal transduction mechanism of the Wnt6/ $\beta$-catenin pathway in MEPM cells.

In addition, the present study identified that compromised Wnt6 activity and $\beta$-catenin signaling in MEPM cells reduced the cytoactivity of Wnt6 and caused cell cycle arrest in G0/G1 phase when compared with control cells. Thus, conditional inhibition of the $\beta$-catenin pathway may disturb the normal cytoactivity of MEPM cells, which may ultimately lead to the development of cleft palate.

It is established that reduced Wnt/ $\beta$-catenin signaling is involved in the development of cleft palate $(21,23-25)$. Furthermore, the Wnt/ $\beta$-catenin signaling pathway has previously been associated with alterations in the viability and apoptosis of MEPM cells (8). These previous findings and the present data suggest that $\mathrm{Wnt} / \beta$-catenin pathway is among the most important signaling cascades for palatal development. However, the exact mechanism regarding the involvement of $\beta$-catenin in MEPM cell activity requires further investigation.

In conclusion, to the best of our knowledge, the present results are the first to indicate that Wnt6/ $\beta$-catenin signaling is involved in the viability of MEPM cells during the stages of palatal shelf elongation and elevation in vitro, thus suggesting that Wnt6/ $\beta$-catenin signaling is involved in the process of palatogenesis.

\section{Acknowledgements}

The present study was supported by the Science and Technology Program of Xiamen City, China (grant no. 3502Z20154074).

\section{References}

1. Mossey PA, Little J, Munger RG, Dixon MJ and Shaw WC: Cleft lip and palate. Lancet 374: 1773-1785, 2009.

2. Fraser FC: The genetics of cleft lip and cleft palate. Am J Hum Genet 22: 336-352, 1970.

3. Schutte BC and Murray JC: The many faces and factors of orofacial clefts. Hum Mol Genet 8: 1853-1859, 1999.

4. Meng T, Shi JY, Wu M, Wang Y, Li L, Liu Y, Zheng Q, Huang L and Shi B: Overexpression of mouse TTF-2 gene causes cleft palate. J Cell Mol Med 16: 2362-2368, 2012.

5. Ferguson MW: Palate development. Development 103 (Suppl): S41-S60, 1988.

6. Wu C, Endo M, Yang BH, Radecki MA, Davis PF, Zoltick PW, Spivak RM, Flake AW, Kirschner RE and Nah HD: Intra-amniotic transient transduction of the periderm with a viral vector encoding TGF $\beta 3$ prevents cleft palate in Tgf $\beta 3(-/-)$ mouse embryos. Mol Ther 21: 8-17, 2013.

7. Meng L, Bian Z, Torensma R and Von den Hoff JW: Biological mechanisms in palatogenesis and cleft palate. J Dent Res 88: 22-33, 2009

8. Feng C, Xu Z, Li Z, Zhang D, Liu Q and Lu L: Down-regulation of Wnt10a by RNA interference inhibits proliferation and promotes apoptosis in mouse embryonic palatal mesenchymal cells through Wnt $/ \beta$-catenin signaling pathway. J Physiol Biochem 69: 855-863, 2013.

9. Li L, Shi JY, Zhu GQ and Shi B: MiR-17-92 cluster regulates cell proliferation and collagen synthesis by targeting TGFB pathway in mouse palatal mesenchymal cells. J Cell Biochem 113: 1235-1244, 2012.

10. Warner DR, Smith HS, Webb CL, Greene RM and Pisano MM: Expression of Wnts in the developing murine secondary palate. Int J Dev Biol 53: 1105-1112, 2009.
11. Warner DR, Mukhopadhyay P, Brock GN, Pihur V, Pisano MM and Greene RM: TGF $\beta-1$ and Wnt-3a interact to induce unique gene expression profiles in murine embryonic palate mesenchymal cells. Reprod Toxicol 31: 128-133, 2011.

12. Miller JR: The Wnts. Genome Biol 3: REVIEWS3001, 2002.

13. Lee HY, Kléber M, Hari L, Brault V, Suter U, Taketo MM, Kemler R and Sommer L: Instructive role of Wnt/beta-catenin of in sensory fate specification in neural crest stem cells. Science 303: 1020-1023, 2004.

14. Miki T, Yasuda SY and Kahn M: Wnt/ $\beta$-catenin signaling in embryonic stem cell self-renewal and somatic cell reprogramming. Stem Cell Rev 7: 836-846, 2011.

15. Kühl SJ and Kühl M: On the role of Wnt/ $\beta$-catenin signaling in stem cells. Biochim Biophys Acta 1830: 2297-2306, 2013.

16. Reya $\mathrm{T}$ and Clevers $\mathrm{H}$ : Wnt signalling in stem cells and cancer. Nature 434: 843-850, 2005.

17. Staal FJ and Luis TC: Wnt signaling in hematopoiesis: Crucial factors for self-renewal, proliferation and cell fate decisions. J Cell Biochem 109: 844-849, 2010.

18. Nusse R: Wnt signaling and stem cell control. Cell Res 18: 523-527, 2008

19. Moon RT, Bowerman B, Boutros M and Perrimon N: The promise and perils of Wnt signaling through beta-catenin. Science 296: 1644-1646, 2002.

20. Angers S and Moon RT: Proximal events in Wnt signal transduction. Nat Rev Mol Cell Biol 10: 468-477, 2009.

21. Jin YR, Han XH, Taketo MM and Yoon JK: Wnt9b-dependent FGF signaling is crucial for outgrowth of the nasal and maxillary processes during upper jaw and lip development. Development 139: 1821-1830, 2012.

22. Jiang Z, Von den Hoff JW, Torensma R, Meng L and Bian Z: Wnt16 is involved in intramembranous ossification and suppresses osteoblast differentiation through the Wnt/ $\beta$-catenin pathway. J Cell Physiol 229: 384-392, 2014.

23. Hu X, Gao J, Liao Y, Tang S and Lu F: Retinoic acid alters the proliferation and survival of the epithelium and mesenchyme and suppresses $\mathrm{Wnt} / \beta$-catenin signaling in developing cleft palate. Cell Death Dis 4: e898, 2013.

24. Hu X, Gao JH, Liao YJ, Tang SJ and Lu F: Dexamethasone alters epithelium proliferation and survival and suppresses Wnt $/ \beta$-catenin signaling in developing cleft palate. Food Chem Toxicol 56: 67-74, 2013.

25. Mostowska A, Hozyasz KK, Wójcicki P, Lasota A, Dunin-Wilczyńska I and Jagodziński PP: Association of DVL2 and AXIN2 gene polymorphisms with cleft lip with or without cleft palate in a Polish population. Birth Defects Res A Clin Mol Teratol 94: 943-950, 2012.

26. Schaale K, Brandenburg J, Kispert A, Leitges M, Ehlers S and Reiling N: Wnt6 is expressed in granulomatous lesions of Mycobacterium tuberculosis-infected mice and is involved in macrophage differentiation and proliferation. J Immunol 191: 5182-5195, 2013.

27. Hitchins L, Fletcher F, Allen S and Dhoot GK: Role of Sulf1A in Wnt1- and Wnt6-induced growth regulation and myoblast hyper-elongation. FEBS Open Bio 3: 30-34, 2012.

28. Wang Q, Lu J, Zhang S, Wang S, Wang W, Wang B, Wang F, Chen Q, Duan E, Leitges M, et al: Wnt6 is essential for stromal cell proliferation during decidualization in mice. Biol Reprod 88: 5, 2013.

29. Beaty TH, Hetmanski JB, Fallin MD, Park JW, Sull JW, McIntosh I, Liang KY, Vanderkolk CA, Redett RJ, Boyadjiev SA, et al: Analysis of candidate genes on chromosome 2 in oral cleft case-parent trios from three populations. Hum Genet 120: 501-518, 2006.

30. Matsumura K, Taketomi T, Yoshizaki K, Arai S, Sanui T, Yoshiga D, Yoshimura A and Nakamura S: Sprouty2 controls proliferation of palate mesenchymal cells via fibroblast growth factor signaling. Biochem Biophys Res Commun 404: 1076-1082, 2011.

31. Thompson MD, Dar MJ and Monga SP: Pegylated interferon alpha targets Wnt signaling by inducing nuclear export of $\beta$-catenin. J Hepatol 54: 506-512, 2011.

32. Kang YJ, Park HJ, Chung HJ, Min HY, Park EJ, Lee MA, Shin Y and Lee SK: Wnt $/ \beta$-catenin signaling mediates the antitumor activity of magnolol in colorectal cancer cells. Mol Pharmacol 82: 168-177, 2012.

33. An JH, Yang JY, Ahn BY, Cho SW, Jung JY, Cho HY, Cho YM, Kim SW, Park KS, Kim SY, et al: Enhanced mitochondrial biogenesis contributes to Wnt induced osteoblastic differentiation of C3H10T1/2 cells. Bone 47: 140-150, 2010. 
34. Kim DY, Park YG, Quan HY, Kim SJ, Jung MS and Chung SH: Ginsenoside Rd stimulates the differentiation and mineralization of osteoblastic MC3T3-E1 cells by activating AMP-activated protein kinase via the BMP-2 signaling pathway. Fitoterapia 83 215-222, 2012.

35. Mao B, Wu W, Li Y, Hoppe D, Stannek P, Glinka A and Niehrs C: LDL-receptor-related protein 6 is a receptor for Dickkopf proteins. Nature 411: 321-325, 2001.

36. Gordon MD and Nusse R: Wnt signaling: Multiple pathways, multiple receptors, and multiple transcription factors. J Biol Chem 281: 22429-22433, 2006.

37. Lhomond G, McClay DR, Gache C and Croce JC: Frizzled1/2/7 signaling directs $\beta$-catenin nuclearisation and initiates endoderm specification in macromeres during sea urchin embryogenesis. Development 139: 816-825, 2012.
38. Krawetz R and Kelly GM: Wnt6 induces the specification and epithelialization of F9 embryonal carcinoma cells to primitive endoderm. Cell Signal 20: 506-517, 2008.

39. Hwang JT and Kelly GM: GATA6 and FOXA2 regulate Wnt6 expression during extraembryonic endoderm formation. Stem Cells Dev 21: 3220-3232, 2012.

40. Lavery DL, Martin J, Turnbull YD and Hoppler S: Wnt6 signaling regulates heart muscle development during organogenesis. Dev Biol 323: 177-188, 2008.

41. Cawthorn WP, Bree AJ, Yao Y, Du B, Hemati N, Martinez-Santibañez G and MacDougald OA: Wnt6, Wnt10a and Wnt10b inhibit adipogenesis and stimulate osteoblastogenesis through a $\beta$-catenin-dependent mechanism. Bone 50: 477-489, 2012. 